\title{
Urinary Leucocyte Excretion in African Subjects : Its Relation to Bacteriuria and the Passage of Bilharzial Ova in Urine
}

\author{
D. C. DUKES,* M.B., CH.B., B.SC., M.R.C.P.; B. R. D. MACDOUGALL†; R. H. ORNE-GLIEMANN $\dagger$ \\ LINDSAY DAVIDSON,* M.D., F.R.C.P.ED., M.R.C.P.
}

Brit. med. F., 1967, 1, 537-538

The rate of leucocyte excretion in the urine of the healthy Caucasian subject is well documented (see Table I) but no corresponding figures have been published for the African. This paper investigates the rate of urinary leucocyte excretion in 49 healthy Africans and in 104 unselected African outpatients, and shows that in the urine (a) leucocyte excretion rates are the same in healthy Africans as in healthy Caucasians, $(b)$ there is no direct relation between the rate of leucocyte excretion and the rate of excretion of bacteria in unselected African outpatients, and $(c)$ there is a significant relation between the rate of excretion of leucocytes and the rate of excretion of bilharzial ova.

\section{Methods}

"Healthy" ambulant subjects whose ages ranged from 5 to 66 years were selected from hospital staff and outpatients, according to the following criteria: (1) absence of urinary symptoms, (2) absence of past history of urinary symptoms or previous bilharzial infection, (3) absence of bilharzial ova in a midday specimen of urine, (4) viable urinary bacteria count of less than $10,000 / \mathrm{ml}$., and (5) absence of bladder calcification on a plain $x$-ray film of the lower abdomen.

The maximal rate of excretion of bilharzial ova occurs between 12 noon and 3 p.m. (Stimmel and Scott, 1956 ; Jordan, 1963). All observations were therefore made on timed collections of urine obtained between these hours.

The rate of leucocyte excretion was determined in duplicate by Houghton and Pears's (1957) modification of the method of Addis (1925). A Neubauer counting-chamber was used in preference to the Fuchs-Rosenthal for specimens with many leucocytes, however, and urine specimens were obtained by natural voiding and not by catheterization. In females the perineum was swabbed with $1: 1,000$ chlorhexidine before micturition. The rate of excretion of bilharzial ova was measured in triplicate by Clarke's (1965) modification of the technique of Bell (1963).

Viable bacteria counts were obtained on mid-stream specimens of urine by the method of O'Sullivan et al. (1960). Counts of over $100,000 / \mathrm{ml}$. were taken to be significant, and below $10,000 / \mathrm{ml}$. non-significant. Counts between 10,000 and $100,000 \mathrm{ml}$. were taken to indicate infection if clinical evidence of urinary infection was also present.

\section{Results}

Healthy Subjects.-The range of leucocyte excretion rates encountered and the mean values in 24 male and 25 female subjects are shown in Table 1 , which also relates our findings to all the published data we have been able to obtain concerning healthy Caucasian subjects. Only two subjects, both female, showed a leucocyte excretion rate greater than 300,000 cells per

- Department of Medicine, University College of Rhodesia, Salisbury. t Medical Students, University College of Rhodesia, Salisbury, Rhodesia. hour, the rates being 321,000 cells and 511,000 cells. per hour respectively.

Unselected Outpatients.-From the results obtained with healthy subjects, the upper limit of normal leucocyte excretion was taken to be 270,000 per hour in males and 500,000 per hour in females. White cell excretion rates in excess of these values were found in 24 out of 45 male patients and in 25 out of 61 female patients. The relation of leucocyte excretion rates to the simultaneous excretion of bilharzial ova and bacteria is shown in Table II.

Among the patients who were not excreting ova, 6 out of 19 males and 13 out of 44 females had abnormally high leucocyte excretion rates. Infection with Trichomonas vaginalis was thought to be responsible for this in five female patients, and two other female patients had significant bacteriuria. One male and two female patients gave a history of past bilharzial infection, and it is possible that their high leucocyte excretion was due to persisting inflammation of the bladder mucosa. Two male patients had a generalized skin rash involving the genitalia and another had neurological impairment of bladder function. In two male and four female patients the cause of the high leucocyte excretion was not apparent.

\section{Discussion}

Bilharzial ova in the urine are commonly accompanied by erythrocytes and also by leucocytes, whose presence may raise the question of accompanying bacterial infection (Powell et al., 1965).

TABLB I.-Urinary Leucocyte Excretion in Healthy Subjects Expressed

\begin{tabular}{|c|c|c|c|c|c|c|}
\hline \multirow{2}{*}{ Author } & \multicolumn{2}{|c|}{ Both Sexes } & \multicolumn{2}{|c|}{ Men } & \multicolumn{2}{|c|}{ Women } \\
\hline & Range & Mean & Range & Mean & Range & Mean \\
\hline Present study ... & $0-511,000$ & 66,000 & $0-$ & 36,000 & $3,400-$ & 95,000 \\
\hline $\begin{array}{l}\text { Addis (1948) } \\
\text { Hamburger } e t a l . \\
\quad(1950) \\
\text { Rofe }(1955) \quad \ldots\end{array}$ & $\overline{-}$ & 30,000 & 27,000 & $\begin{array}{l}- \\
-\end{array}$ & 511,000 & - \\
\hline $\begin{array}{l}\text { Lippman (1957) } \\
\text { Houghton and } \\
\text { Pears (1957) } \\
\text { Hutt et al. (1961) }\end{array}$ & $\begin{array}{c}18 \overline{, 000} \\
196,000 \\
0-200,000\end{array}$ & $\begin{array}{c}27,000 \\
66,000 \\
-\end{array}$ & 130,000 & $\begin{array}{l}47,500^{*} \\
\text { to } 87,000\end{array}$ & $\overline{-}$ & $\begin{array}{l}56, \overline{400^{*}} \\
\text { to } 66,000\end{array}$ \\
\hline Little (1962) .. & $0-574,000$ & $=$ & $\begin{array}{c}\overline{0-} \\
220,000\end{array}$ & $46, \overline{000}$ & $\frac{\overline{0}}{574,000}$ & $74, \overline{000}$ \\
\hline
\end{tabular}

* These figures refer to mean values obtained at different times of day and under different conditions of exercise.

TABLE II.-Excretion of Leucocytes, Bacteria, and Bilharzial Ova in an

\begin{tabular}{|c|c|c|c|c|c|}
\hline \multirow{2}{*}{ Sex } & \multirow{2}{*}{$\begin{array}{l}\text { Presence of } \\
\text { Bilharzial } \\
\text { Ova }\end{array}$} & \multirow{2}{*}{$\begin{array}{l}\text { Significant } \\
\text { Bacteriuria }\end{array}$} & \multirow{2}{*}{$\begin{array}{l}\text { No. of } \\
\text { Patients }\end{array}$} & \multicolumn{2}{|c|}{ Hourly Leucocyte Excretion } \\
\hline & & & & Range & Mean \\
\hline 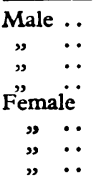 & $\begin{array}{l} \pm \\
\pm \\
\pm \\
+ \\
\pm \\
-\end{array}$ & $\begin{array}{l} \pm \\
+ \\
\pm \\
+ \\
+ \\
-\end{array}$ & $\begin{array}{r}1 \\
25 \\
0 \\
19 \\
2 \\
15 \\
2 \\
42\end{array}$ & $\begin{array}{c}-\overline{8}, 000-29,000,000 \\
0-1,955,000 \\
333,000-8,700,000 \\
10,000-100,000,000 \\
1,432,000-2,257,000 \\
16,000-4,403,000\end{array}$ & $\begin{array}{r}16,600,000 \\
8,350,000 \\
3 \overline{384,000} \\
4,516,000 \\
9,390,000 \\
1,844,000 \\
706,000\end{array}$ \\
\hline
\end{tabular}


In the temperate zones the presence of an abnormally large number of leucocytes in the urine is useful in the diagnosis of pyelonephritis (Hutt et al., 1961), though there is not always a direct relation between the rate of excretion of leucocytes and the bacterial content of urine (Bradley and Little, 1963). In view of the suspected association of pyelonephritis with urinary bilharziasis (Gelfand, 1964), we felt that it was important, in trying to assess the diagnostic significance of leucocyte excretion in the African, to see if this was modified by the presence of parasitic infestation.

Table I shows that in Africans whose state of health was defined by rigid criteria the rate of excretion of leucocytes was within the limits found in healthy Caucasian stock in temperate climates. In the group of unselected African outpatients, however, nearly half were excreting leucocytes at rates above these limits. Table II shows that the increase in mean rate of leucocyte excretion in patients who were passing bilharzial ova was striking; it was on the average at least 12 times greater among patients who were passing ova than in those who were not. This increase in leucocyte excretion was not due to bacterial infection,

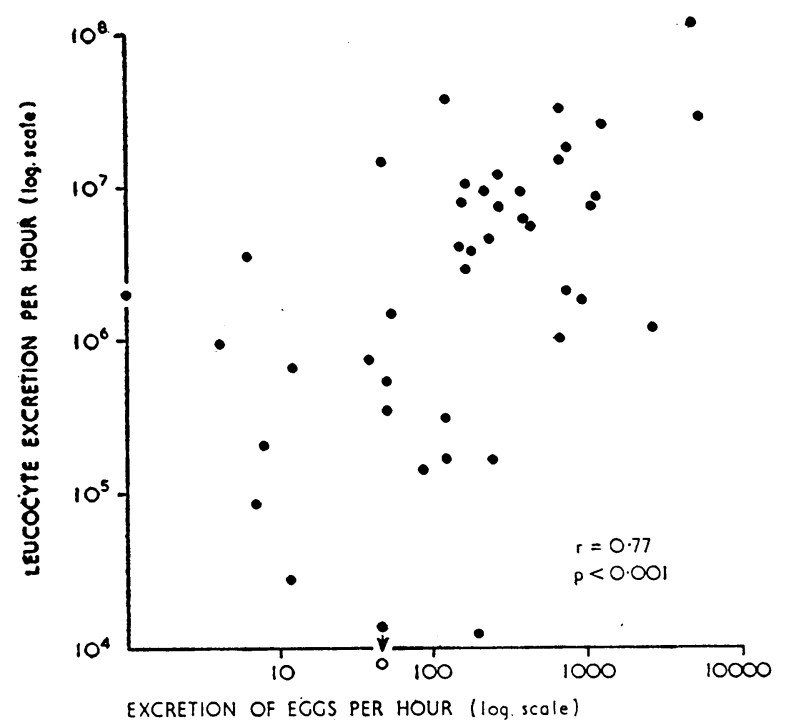

Relation between simultaneous rates of urinary excretion of bilharzial ova and leucocytes.

for of the 106 patients examined only five had significant bacteriuria, and two of these were not passing ova. A high rate of leucocyte excretion, which could not be explained by infection, was found in eight patients who were not passing ova. Two of them gave a past history of bilharziasis and others may have had the disease without knowing it. It is probable that changes in the lower urinary tract resulting from chronic bilharziasis are accompanied by an increased rate of leucocyte excretion, even in the absence of ova detectable at a single examination.

The technique of cell counting employed by us did not allow differential leucocyte counts to be made. Preliminary results obtained with urine smears treated with Leishman's stain, however, support the finding of Powell et al. (1965) that a high proportion of leucocytes excreted by patients with urinary bilharziasis are eosinophils.

Among patients infected with bilharzia there is a significant positive correlation between the rate of leucocyte excretiun and the rate of egg excretion, as shown in the Chart $(r=+0.77$ $\mathrm{P}<0.001)$. The most likely explanation is that the lescocytes are derived from inflammatory exudate which accompanies the eggs escaping from the bladder mucosa.

Our observations show that urinary bilharziasis causes an increase in the rate of excretion of leucocytes in the urine of a magnitude sufficient to mask the increase in urinary white cell excretion accompanying any associated parenchymal renal disease. The excretion rate of urinary white cells is therefore of little value in the diagnosis of pyelonephritis in areas where urinary bilharziasis is endemic.

\section{Summary}

The rate of urinary leucocyte excretion was measured in 24 male and 25 female healthy African subjects. The values determined agree closely with those previously published for normal Caucasian subjects.

Urinary leucocyte excretion was measured in 106 unselected African outpatients, 43 of whom were passing bilharzial ova. The rate of leucocyte excretion was much greater among those who had urinary bilharziasis than those who did not.

The rate of leucocyte excretion in patients with bilharziasis was unrelated to bacteriuria, but was directly proportional to the rate of egg excretion.

Quantitative examination of the cellular content of the urine is likely to be of little diagnostic value in patients with renal parenchymal disease who also have urinary bilharziasis.

We acknowledge the award of a Julius Robinson Scholarship for undergraduate research to one of us (B. R. D. M.). We thank Professor $M$. Gelfand for encouragement and advice, and Mrs. F. W. Huddle, B.Sc., and Sister M. Gray and staff at Harare Hospital for their assistance in this study.

\section{REFERENCES}

Addis, T. (1925). F. Amer. med. Ass., 85, 163.

- (1948). Glomerular Nephritis. New York

Bell, D. R. (1963). Bull. Wld Hlth Org., 29, 525.

Bradley, J. M., and Little, P. J. (1963). Brit. med. F., 2, 361

Clarke, H. V. de V. (1965). Dissertation for the degree of Doctor of Philosophy, Rhodes University.

Gelfand, M. (1964). Cent. Afr. F. Med., 10, 1

Hamburger, J., Mathé, G., and de Verbizier, J. (1950). Ann. Biol. clin., 8,627 .

Houghton, B. J., and Pears, M. A. (1957). Brit. med. F., 1, 622.

Hutt, M S. R., Chalmers, J. A., MacDonald, J. S., and de Wardener, H. E. (1961). Lancet, 1, 351.

Jordan, P. (1963). E. Afr. med. f., 40, 250.

Lippman, R. W. (1957). Urine and the Urinary Sediment, 2nd ed. Springfield.

Little, P. J. (1962). Lancet, 1, 1149. (1960). f. clin. Path., 13, 527 .

Powell, S. J., Maddison, S. E., and Elsdon-Dew, R. (1965). S. Afr. med. F., 39, 165 .

Rofe, P. (1955). f. clin. Path., 8, 25.

Stimmel, Carolyn, M., and Scott, J. A. (1956). Tex. Rep. Biol. Med., 14,440 . 